Prepared in cooperation with Bureau of Reclamation

\title{
Biological Data for Water in Lake Powell and from Glen Canyon Dam Releases, Utah and Arizona, 1990-2009
}

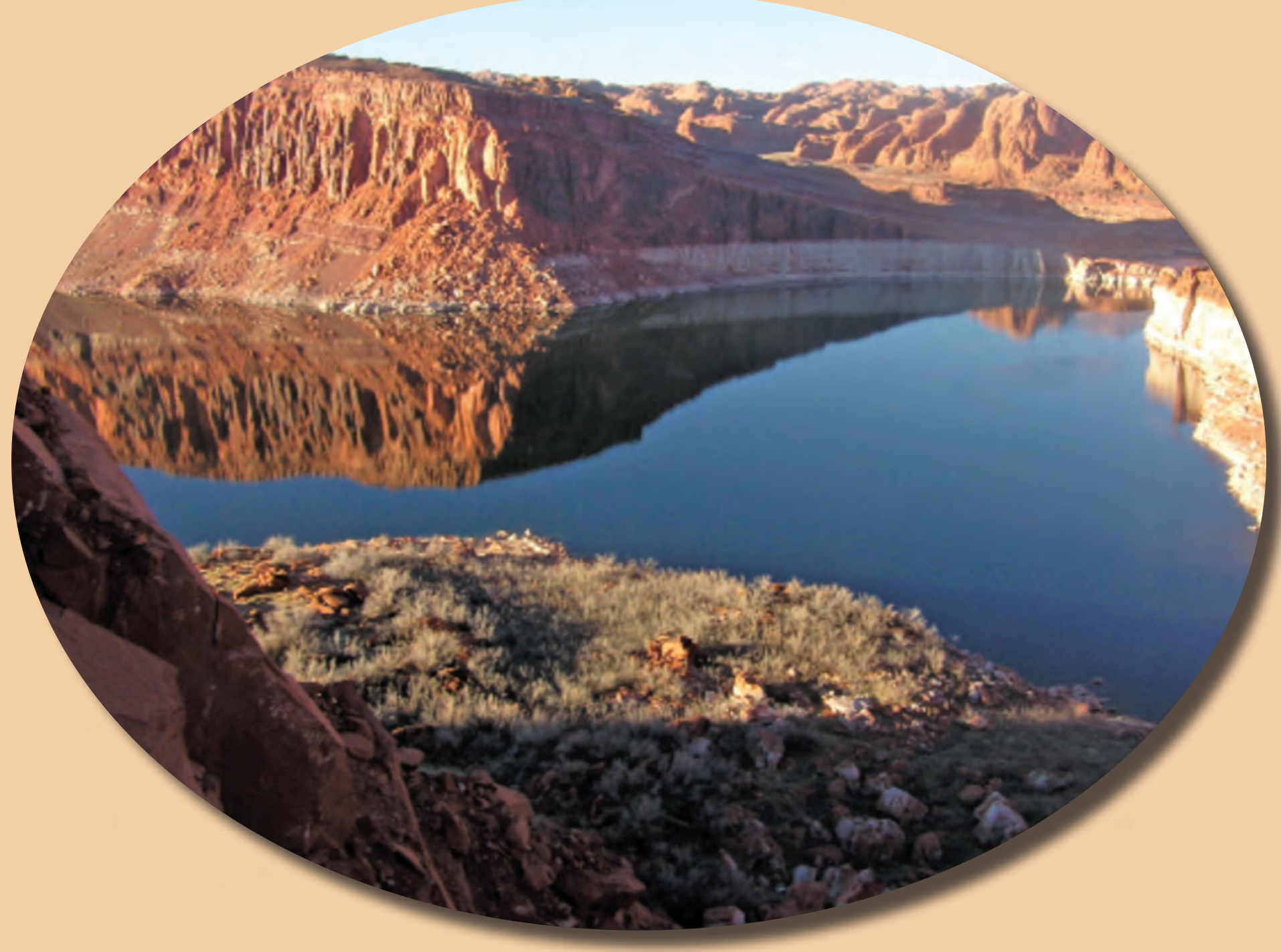

Data Series 959

U.S. Department of the Interior

U.S. Geological Survey 
COVER. Photograph of the San Juan River arm of Lake Powell downstream of Wilson Creek, Utah (USGS photograph by William Vernieu). 


\section{Biological Data for Water in Lake Powell and from Glen Canyon Dam Releases, Utah and Arizona, 1990-2009}

By William S. Vernieu

Prepared in cooperation with Bureau of Reclamation

Data Series 959 


\title{
U.S. Department of the Interior SALLY JEWELL, Secretary
}

\section{U.S. Geological Survey Suzette M. Kimball, Acting Director}

\author{
U.S. Geological Survey, Reston, Virginia: 2015
}

For more information on the USGS - the Federal source for science about the Earth, its natural and living resources, natural hazards, and the environment—visit http://www.usgs.gov or call 1-888-ASK-USGS.

For an overview of USGS information products, including maps, imagery, and publications, visit http://www.usgs.gov/pubprod/.

Any use of trade, firm, or product names is for descriptive purposes only and does not imply endorsement by the U.S. Government.

Although this information product, for the most part, is in the public domain, it also may contain copyrighted materials as noted in the text. Permission to reproduce copyrighted items must be secured from the copyright owner.

Suggested citation:

Vernieu, W.S., 2015, Biological data for water in Lake Powell and from Glen Canyon Dam releases, Utah and Arizona, 1990-2009: U.S. Geological Survey Data Series 959, 12 p., http://dx.doi.org/10.3133/ds959.

ISSN 2327-638X (online) 


\section{Acknowledgments}

Data presented in this report were collected by various offices of the Bureau of Reclamation (Reclamation) and the U.S. Geological Survey (USGS) with the cooperation of the National Park Service (NPS) Glen Canyon National Recreation Area. The author wishes to acknowledge and thank the following people for their assistance and participation in this data-collection effort. Technical field support since 1992 was provided by Robert Radtke, Nick Williams, Jeanne Korn, Mike Horn (Reclamation), Kevin Berghoff, Murph Doty, Mark Anderson, Jesse Granet, and Carolyn Hackbarth (NPS), and Susan Hueftle and Nick Voichick (USGS). In addition to field support, specific acknowledgement is given to Susan Hueftle (USGS), who developed sampling rationale, methods, and data analysis of the biological data collected from Lake Powell. Her work formed the basis of the existing biological monitoring program. Since the inception of the Lake Powell water-quality monitoring program, Reclamation has provided the primary funding for this program.

\section{Contents}

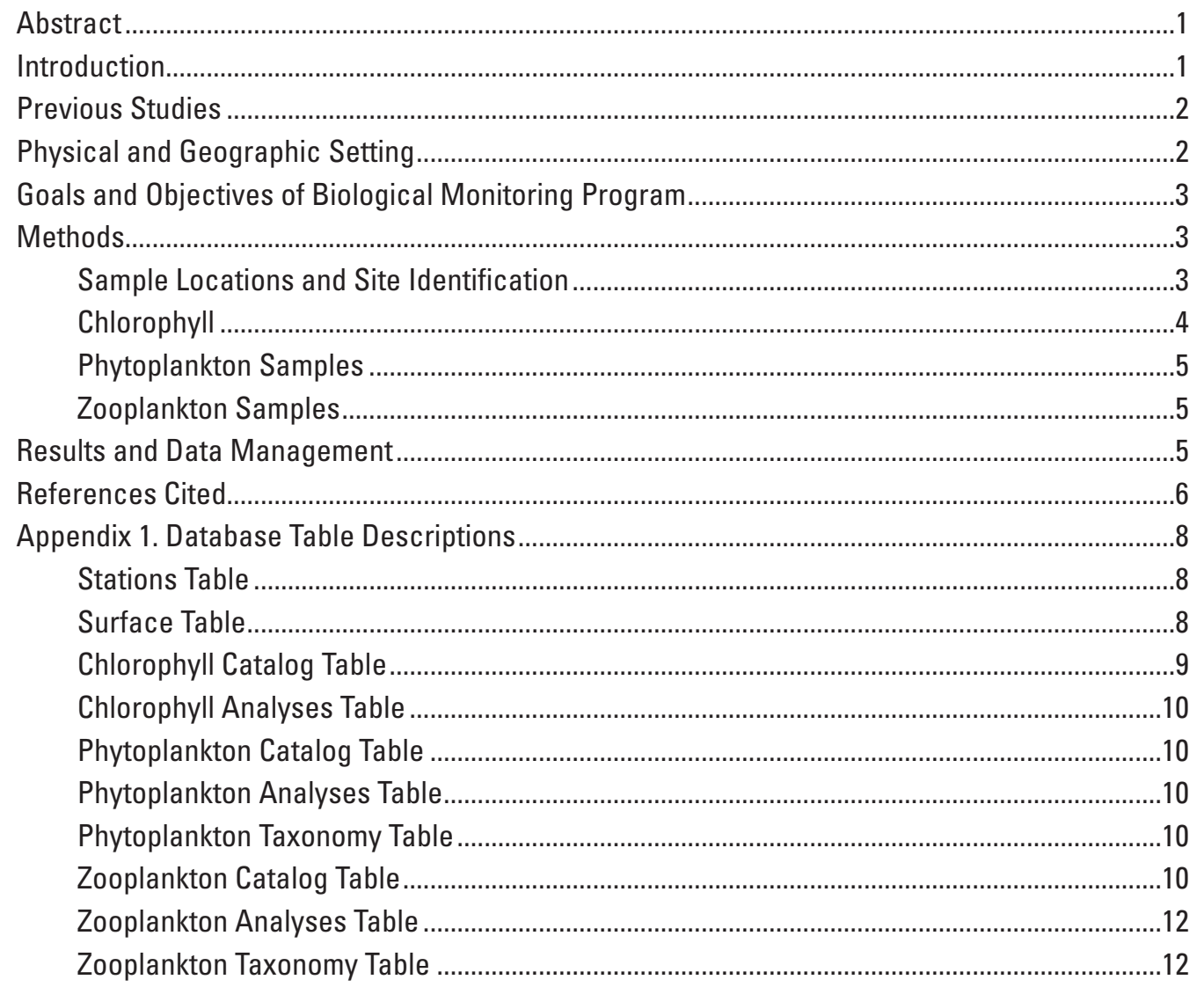




\section{Figures}

1. Map showing the geographic setting of Lake Powell with biologic sampling locations indicated by small black triangles....

2. Database relationship diagram for biological components of the WODB (water-quality database)

\section{Tables}

1. Listing of the primary station groups for biological samples in the WODB (water-quality database)

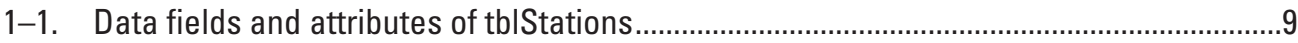

1-2. Data fields and attributes of tblSurface ……….........................................................

1-3. Data fields and attributes of tblChlorophyll Catalog ........................................................

1-4. Data fields and attributes of tbIChlorophyll Analyses......................................................11

1-5. Data fields and attributes of tblPhytoplankton Catalog ..................................................11

1-6. Data fields and attributes of tblPhytoplankton Analyses .................................................11

1-7. Data fields and attributes of tblPhtyoplankton Taxonomy ................................................11

1-8. Data fields and attributes of tblZooplankton Catalog .......................................................11

1-9. Data fields and attributes of tblZooplankton Analyses....................................................12

1-10. Data fields and attributes of tblZooplankton Taxonomy .................................................12 


\section{Conversion Factors}

\begin{tabular}{lcl}
\multicolumn{1}{c}{ Multiply } & \multicolumn{1}{c}{ By } & \multicolumn{1}{c}{ To obtain } \\
\hline micrometer $(\mu \mathrm{m})$ & \multicolumn{1}{c}{ Length } & \\
millimeter $(\mathrm{mm})$ & 0.00003937 & inch (in.) \\
centimeter $(\mathrm{cm})$ & 0.03937 & inch (in.) \\
meter $(\mathrm{m})$ & 0.3937 & inch (in.) \\
kilometer $(\mathrm{km})$ & 3.281 & foot (ft) \\
& 0.6214 & mile (mi) \\
\hline hectare $(\mathrm{ha})$ & \multicolumn{1}{c}{ Area } & acre \\
square kilometer $\left(\mathrm{km}^{2}\right)$ & 2.471 & square mile (mi $\left.{ }^{2}\right)$ \\
\hline liter $(\mathrm{L})$ & 0.3861 & ounce, fluid (fl. oz) \\
liter $(\mathrm{L})$ & Volume & gallon (gal) \\
cubic meter $\left(\mathrm{m}^{3}\right)$ & 33.82 & gallon (gal) \\
cubic meter $\left(\mathrm{m}^{3}\right)$ & 0.2642 & acre-foot (acre-ft) \\
cubic kilometer & 264.2 & million acre-foot (acre-ft) \\
\hline & 0.0008107 & \\
\hline cubic meter per second $\left(\mathrm{m}^{3} / \mathrm{s}\right)$ & 0.8107 & cubic foot per second (ft $3 / \mathrm{s})$ \\
\hline
\end{tabular}

\section{Supplemental Information}

Temperature in degrees Celsius $\left({ }^{\circ} \mathrm{C}\right)$ may be converted to degrees Fahrenheit $\left({ }^{\circ} \mathrm{F}\right)$ as ${ }^{\circ} \mathrm{F}=\left(1.8 \times{ }^{\circ} \mathrm{C}\right)+32$. 



\title{
Biological Data for Water in Lake Powell and from Glen Canyon Dam Releases, Utah and Arizona, 1990-2009
}

\author{
By William S. Vernieu
}

\section{Abstract}

Biological samples from various locations on Lake Powell and in the Colorado River in the tail water downstream of Glen Canyon Dam were collected by the Bureau of Reclamation and U.S. Geological Survey from December 1990 through December 2009 as part of a long-term water-quality monitoring program that began in 1964. These samples consisted of discrete (1-m deep) chlorophyll samples, discrete (1-m deep) wholewater phytoplankton samples, and 30-m vertically composited zooplankton samples filtered through an $80-\mu$ m plankton net. Chlorophyll concentration was determined by acetone extraction followed by trichromatic spectroscopy on 2,051 samples. Phytoplankton analysis consisted of identification to the genus or species level, enumeration, and estimation of biovolume on 1,397 samples. Phytoplankton analysis identified 646 different phytoplankton taxa. Zooplankton analysis consisted of identification to the genus or species level, enumeration, and estimation of biomass from 1,898 samples. Zooplankton analysis identified 114 different zooplankton taxa.

The results of these analyses are presented in this report. From this record, further interpretation may be made concerning primary and secondary production in Lake Powell. These data provide a linkage between physical and chemical water-quality data and fisheries investigations in Lake Powell. They also provide information regarding the export of biological material from Glen Canyon Dam.

\section{Introduction}

Water-quality monitoring in Lake Powell and from the Glen Canyon Dam (GCD) tail waters was inititated by the Bureau of Reclamation (Reclamation) in 1964, shortly after closure of the dam in March 1963. The U.S. Geological Survey (USGS) has been responsible for this program since 1996. Details of the various phases of the water-quality monitoring program, including corresponding physical and chemical data from the Lake Powell monitoring program, are described in Vernieu (2015). As part of this long-term water-quality monitoring program on Lake Powell, one set of zooplankton samples was collected from the reservoir in December 1990, and regular collection of biological samples began in 1992. These samples consist of discrete (1-m-deep) chlorophyll samples, discrete (1-m-deep) whole-water samples for phytoplankton analysis, and 30-m vertically composited zooplankton samples filtered through an $80-\mu \mathrm{m}$ plankton net. The results of these analyses from 1990 through 2009 are presented in this report.

Biological data from the Lake Powell monitoring program, in addition to physical and chemical data described in Vernieu (2015), are organized in separate tables of the WQDB (a nominal acronym for water-quality database). The WQDB is a Microsoft Access relational database consisting of tables of similar information linked by common fields and was developed to store data and assist in organizing, analyzing, and interpreting this information. Tables for physical and chemical data describe sampling site information, site visits, ambient observations associated with a site visit, depth profiles of physicochemical parameters through the water column, and results of chemical analyses for water samples for major ionic and nutrient constituents. In addition, individual biological data tables describe collection information and results of analyses for chlorophyll, phytoplankton, and zooplankton samples, as well as taxonomic indices for phytoplankton and zooplankton organisms identified to aid in summarization by major taxonomic divisions.

A description of the physical and chemical components of the WQDB and contents of the associated data files are available at http://pubs.usgs.gov/ds/471/. These files contain the WQDB Microsoft Access database (WQDB.mbd), comma-separatedvalues (CSV) files of each of the database tables, and CSV files representing the output of predefined sample queries, which combine data from select tables. Further assistance and other data formats are available from the author.

The dynamics of the aquatic biologic community have linkages throughout the food web, both aqueous and terrestrial (Wetzel, 2001; Thornton and others, 1990; Horne and Goldman, 1994). Primary production is the creation of biomass from photosynthesis in algal organisms and is directly dependent on the physical and chemical conditions of the aquatic ecosystem. Secondary production is the creation of biomass from consumption of primary producers by herbivorous organsims. For the purposes of this report, primary production in Lake Powell is represented by phytoplankton, the part of the planktonic community consisting of microscopic, plantlike organisms. Secondary production is represented by zooplankton, the part of the planktonic community consisting of small organisms that feed on phytoplankton and other smaller forms of zooplankton. Therefore, phytoplankton and zooplankton provide a linkage between chemical and physical water quality and higher trophic levels (Hutchinson, 1967). Furthermore, the export of the phytoplankton and zooplankton from Glen Canyon Dam releases to the Colorado River forms the basis of the downstream aquatic 
foodbase in Grand Canyon (Angradi and others, 1992; Ayers and McKinney, 1996).

The purpose of this report is to publish currently available biological data from the Lake Powell water-quality monitoring program in addition to previously published physicochemical data from Lake Powell. These publications provide a source of existing data from which interpretations of patterns and processes in Lake Powell may be made and allow comparisons to other similar lakes and reservoirs.

\section{Previous Studies}

Prior to 1992, a number of short-term biological sampling efforts were performed both in Lake Powell and below GCD by agencies outside Reclamation. Most efforts focused on the fisheries and food-base characteristics of the planktonic community. From 1967 to 1970, Stone (1966, 1967), Stone and Queenan (1967), and Stone and Rathbun (1968a, 1968b, 1969a, 1969b) conducted studies that focused on tail-water food-base sources. Stewart and others (1974), Blinn and others (1976), and Stewart and Blinn (1976) investigated reservoir diatom assemblages and their relationship to light penetration and other chemical and physical factors. Between 1981 and 1987, Haury (1986) collected a series of six qualitative, quasi-annual reservoir zooplankton collections. Subsequent studies of lake plankton dynamics were performed by Sollberger and others (1988), who evaluated lakewide community structure, health, and biomass implications for fisheries sustainability in 1987 and 1988. Angradi and others (1992) did a comprehensive analysis of the effects of dam operations on the tail-water food/energy base in the early 1990s. This effort was complemented by work done by Ayers and McKinney (1996) in the forebay of GCD at the same time.

From 1995 to 1998, Mueller and Horn (1999) used hydroacoustic sensors to quantify fisheries and zooplankton communities in the reservoir. Few efforts have attempted to analyze trends enduring more than a few years or to characterize the system by applying planktonic community characteristics as indicators of trophic status, water-quality status, or ecosystem health.

\section{Physical and Geographic Setting}

Glen Canyon Dam was completed on March 13, 1963, and represents the primary storage unit of the Colorado River Storage Project. Glen Canyon Dam, constructed and operated by Reclamation, impounds the Colorado River to form Lake Powell. Lake Powell is located on the border of Utah and Arizona within Glen Canyon National Recreation Area, upstream of Glen Canyon Dam, 2 miles northwest of Page, Ariz. (fig. 1). At a full pool elevation of $1,128 \mathrm{~m}(3,700 \mathrm{ft})$, Lake Powell has a capacity of $32.336 \mathrm{~km}^{3}$ (26.214 million acre-feet) (Ferrari, 1988), a surface area of 65,069 hectares (160,784 acres), and extends $290 \mathrm{~km}$ (180 mi) upstream, with an estimated shoreline length of $3,057 \mathrm{~km}$ (1,900 mi). The drainage area above Lake Powell is $279,000 \mathrm{~km}^{2}\left(108,000 \mathrm{mi}^{2}\right)$ (Stanford and Ward, 1991).
Figure 1. Map showing the geographic setting of Lake Powell with biologic sampling locations indicated by small black triangles.

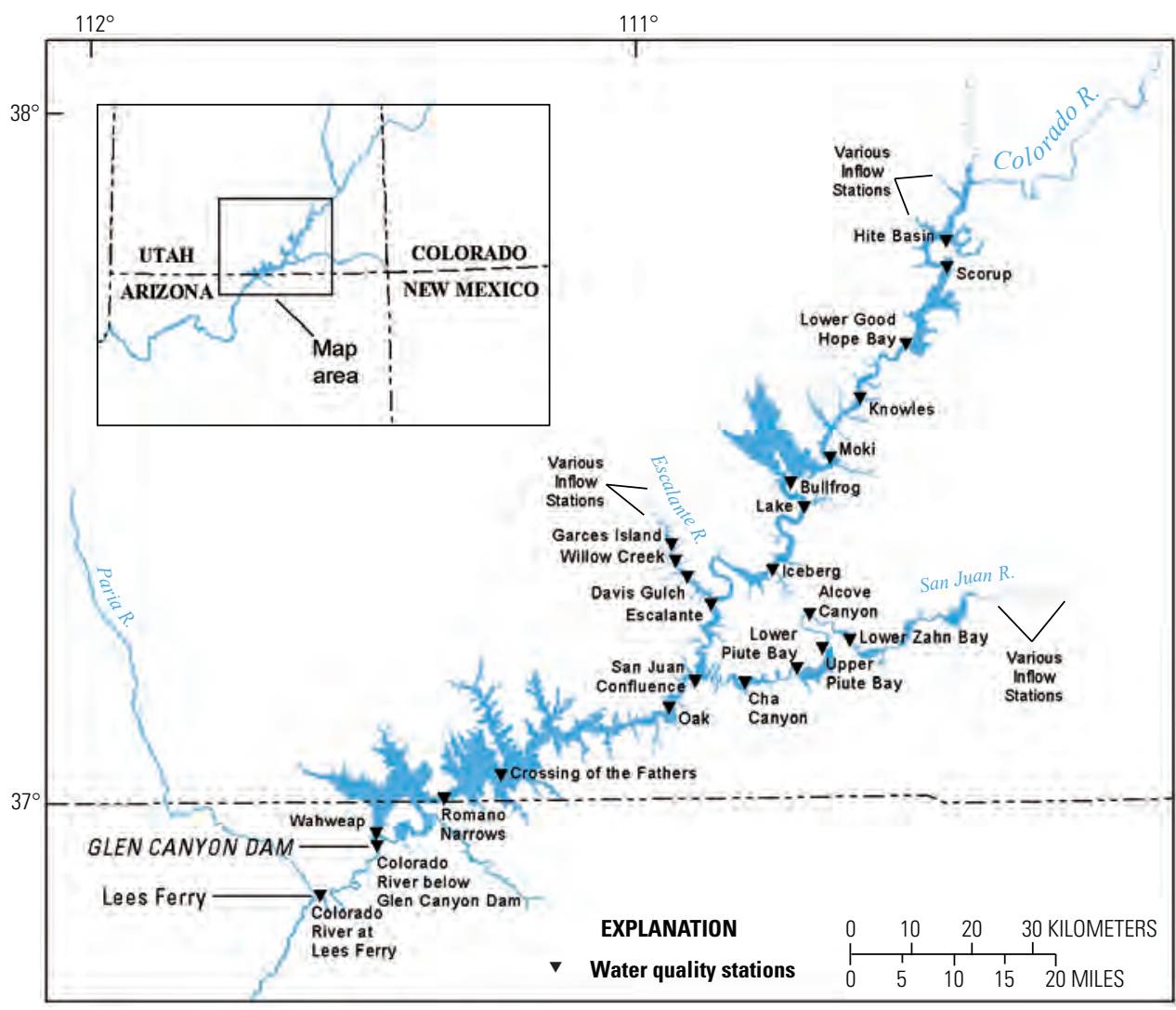




\section{Goals and Objectives of Biological Monitoring Program}

The goal of the Lake Powell biological monitoring program is to characterize, both in the reservoir and within the tail waters, long-term, seasonal, and spatial trends in abundance, community structure, and primary and secondary productivity. Specific objectives of the program include the following:

- Characterize primary production in the reservoir and tail waters.

- Characterize secondary production of the reservoir and tail waters.

- Characterize the export of biological material from Glen Canyon Dam releases.

- Use biological indicators to evaluate water-quality trends.

\section{Methods}

Throughout this discussion, references will be made to the WQDB, a database that contains the information from the Lake Powell monitoring program. Data from various components of the monitoring program are stored in separate tables of the database. The linkages that exist between the various tables are graphically represented in figure 2. Further details of the structure and content of each of the specific tables are discussed in the appendix.

\section{Sample Locations and Site Identification}

Standard locations for biological monitoring in Lake Powell are described in the Stations table (tblStations) of the WQDB (Vernieu, 2015). In most cases, sample locations were selected to represent major distinct areas of the reservoir and were located in the thalweg of the original river channel at or near channel constrictions. Twenty-seven primary stations were established at which quarterly biological monitoring was performed (table 1). These primary stations include inflow areas of the major tributaries

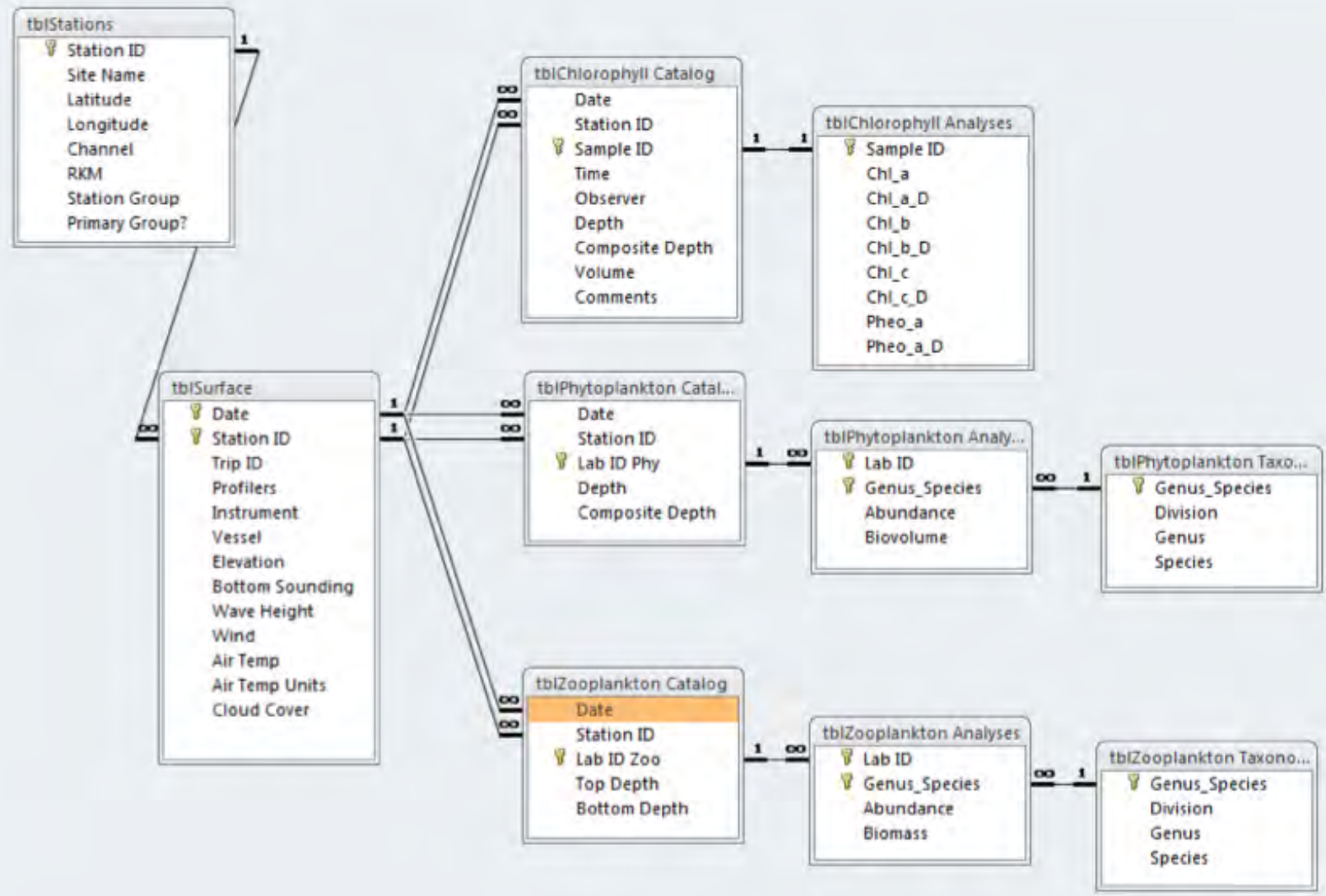

Figure 2. Database relationship diagram for biological components of the WODB (water-quality database). 
Table 1. Listing of the primary station groups for biological samples in the WODB (water-quality database).

[Channel codes: CR, Colorado River; SJR, San Juan River; ESC, Escalante River. RKM, river-channel kilometers; \#, number]

\begin{tabular}{|c|c|c|c|c|c|c|c|}
\hline $\begin{array}{l}\text { Station } \\
\text { group }\end{array}$ & Station ID & Site name & Latitude & Longitude & Channel & RKM & $\begin{array}{c}\text { \# of site } \\
\text { visits }\end{array}$ \\
\hline LPCR-249 & LPCR-249 & Colorado River at Lees Ferry & 36.865241 & -111.584485 & $\mathrm{CR}$ & -24.9 & 163 \\
\hline LPCR0000 & LPCR0000 & Glen Canyon Dam draft tubes & variable & variable & $\mathrm{CR}$ & 0 & 162 \\
\hline LPCR0024 & LPCR0024 & Wahweap & 36.955278 & -111.482778 & CR & 2.4 & 203 \\
\hline LPCR0250 & LPCR0250 & Romano Narrows & 37.005474 & -111.3606156 & CR & 25.0 & 2 \\
\hline LPCR0453 & LPCR0453 & Crossing of the Fathers & 37.039333 & -111.256944 & $\mathrm{CR}$ & 45.3 & 69 \\
\hline LPCR0905 & LPCR0905 & Oak & 37.134444 & -110.952222 & CR & 90.5 & 70 \\
\hline LPCR1001 & LPCR1001 & San Juan R. Confluence & 37.172744 & -110.904269 & CR & 100.1 & 45 \\
\hline LPCR1169 & LPCR1169 & Escalante & 37.283056 & -110.874444 & CR & 116.9 & 67 \\
\hline LPCR1395 & LPCR1395 & Iceberg & 37.332731 & -110.762581 & CR & 139.5 & 50 \\
\hline LPCR1587 & LPCR1587 & Lake & 37.422500 & -110.703056 & $\mathrm{CR}$ & 158.7 & 49 \\
\hline LPCR1679 & LPCR1679 & Bullfrog & 37.470556 & -110.725000 & CR & 169.2 & 69 \\
\hline LPCR1799 & LPCR1799 & Moki & 37.484492 & -110.645733 & $\mathrm{CR}$ & 177.2 & 44 \\
\hline LPCR1933 & LPCR1933 & Knowles & 37.579247 & -110.598806 & $\mathrm{CR}$ & 193.3 & 51 \\
\hline LPCR2085 & LPCR2085 & Lower Good Hope Bay & 37.657222 & -110.514167 & $\mathrm{CR}$ & 208.5 & 69 \\
\hline LPCR2255 & LPCR2255 & Scorup & 37.767222 & -110.436389 & $\mathrm{CR}$ & 225.5 & 67 \\
\hline LPCR2387 & LPCR2387 & Hite Basin & 37.805278 & -110.436944 & $\mathrm{CR}$ & 238.7 & 70 \\
\hline LPCR_INF & LPCR_INF & Colorado River Inflow Stations & variable & variable & $\mathrm{CR}$ & 999 & 76 \\
\hline LPESC119 & LPESC119 & Escalante at Davis Gulch & 37.324167 & -110.917222 & ESC & 11.9 & 61 \\
\hline LPESC200 & LPESC200 & Escalante at Willow Creek & 37.346389 & -110.938056 & ESC & 20 & 46 \\
\hline LPESC273 & LPESC273 & Escalante Inflow above Garces Island & 37.370510 & -110.944223 & ESC & 27.3 & 28 \\
\hline LPESCINF & LPESCINF & Escalante River Inflow Stations & variable & variable & ESC & 999 & 43 \\
\hline LPSJR193 & LPSJR193 & San Juan at Cha Canyon & 37.170000 & -110.813889 & SJR & 19.3 & 71 \\
\hline LPSJR329 & LPSJR329 & San Juan at Lower Piute Bay & 37.188889 & -110.719167 & SJR & 32.9 & 61 \\
\hline LPSJR431 & LPSJR431 & San Juan at Upper Piute Bay & 37.218889 & -110.673056 & SJR & 43.1 & 67 \\
\hline LPSJR530 & LPSJR530 & San Juan at Alcove Canyon & 37.267758 & -110.696148 & SJR & 53 & 16 \\
\hline LPSJR625 & LPSJR625 & San Juan at Lower Zahn Bay & 37.229444 & -110.623611 & SJR & 62.5 & 42 \\
\hline LPSJRINF & LPSJRINF & San Juan River Inflow Stations & variable & variable & SJR & 999 & 55 \\
\hline
\end{tabular}

to the reservoir (Colorado, San Juan, and Escalante Rivers), tail-water locations immediately below Glen Canyon Dam and at Lees Ferry, Ariz., 14 sites on the Colorado River main channel arm of the reservoir, 5 sites on the San Juan River arm, and 3 sites on the Escalante River arm. Some primary stations were not always sampled because of low reservoir elevations, and other nonprimary stations were occasionally sampled where interesting or unusual conditions existed. Currently, 21 to 37 stations may be sampled on a given quarterly survey.

The primary stations are also used to define the 27 station groups, which are used to group stations whose STATION ID values have changed over the monitoring history or whose actual locations have been slightly adjusted because of boat traffic, wind patterns, or local sedimentation. Because information is stored in the WQDB according to the STATION ID field in use at the time of collection, the STATION GROUP field is used to to collectively reference multiple STATION IDs to a single representative location on the reservoir.

\section{Chlorophyll}

Chlorophyll samples were collected at most reservoir sampling locations (fig. 1) at a depth of $1 \mathrm{~m}$ and filtered through a 47-mm Whatman GF/C or Gelman A/E glass fiber filter with a peristaltic pump. Samples from the Glen Canyon Dam tail water and inflow tributaries were collected from grab samples in wellmixed flowing water. Because of low chlorophyll concentrations in Lake Powell compared to more productive waters, volumes of $4 \mathrm{~L}$ or more were filtered, except in cases where suspended solids in the samples reduced filtration rates or insufficient volumes of sample were collected. Filters were then removed from the filter holder, assessed for general color, folded in half, patted dry to remove excess moisture, and placed in an envelope labeled with the station name, date, time, collection depth, and volume of water filtered. From 1992 to 2000, samples were stored on dry ice immediately after collection and kept frozen until analysis. From 2001 to 2009, samples were dried in a desiccating chamber 
immediately after collection and stored under dark conditions prior to analysis. Sample collection information was stored with other sampling observations and measurements in the Chlorophyll Catalog table (tblChlorophyll Catalog) of the WQDB. See the appendix for further details about the Chlorophyll Catalog table.

Chlorophyll analysis followed procedures detailed by Clesceri and others (1999) for the spectrophotometric determination of chlorophyll by the trichromatic method (section SM10200 H). Pigment extraction was performed by macerating the filters in an acetone solution. The extract was then analyzed by spectrophotometery for optical density at wavelengths of 664, 647, and $630 \mathrm{~nm}$, subtracting optical density at $750 \mathrm{~nm}$ as a turbidity correction. Chlorophyll $a, b$, and $c$ concentrations were determined by the trichromatic equation (Jeffery and Humphrey, 1975). Chlorophyll $a$ may be overestimated by including pheopigments, degradation pigments of chlorophyll resulting from the loss of the central $\mathrm{Mg}^{+2}$ ion of a chlorophyll molecule, that absorb near the same wavelength as chlorophyll $a$. Pheophytin analysis involves the addition of acid to the sample, converting chlorophyll $a$ to pheophytin $a$, and is used to provide an evaluation of the physiologic condition of the chlorophyll-containing organisms. Pheophytin analyses were performed on samples collected after September 2002. From 1992 to 1996, chlorophyll sample analysis was performed by Reclamation's Environmental Sciences Section Laboratory in Denver, Colorado. From 1996 to 2009, chlorophyll analyses were performed by Reclamation's Lower Colorado Regional Laboratory in Boulder City, Nevada.

\section{Phytoplankton Samples}

Samples for phytoplankton analysis consisted of a 1-L sample collected from a depth of $1 \mathrm{~m}$ at reservoir sampling locations. Samples from the Glen Canyon Dam tail water and inflow tributaries were collected from grab samples in well-mixed flowing water. These samples were preserved with acid Lugols solution (Clesceri and others, 1999) until analyzed. Sample collection information was stored in the Phytoplankton Catalog table (tblPhytoplankton Catalog) of the WQDB.

Analysis consisted of enumeration and identification to the species level. Slides were prepared using membrane filtration and examined at several magnifications. Abundance of common taxa was estimated by random field counts; rarer taxa were quantified by scanning an entire strip of the filter. In accordance with Lund and others (1958), counts are reported to be accurate within 90-percent confidence limits. Phytoplankton analysis was performed by BSA Environmental Services, Inc., Beachwood, Ohio.

\section{Zooplankton Samples}

Zooplankton samples were collected from reservoir locations by $30-\mathrm{m}$ vertical tows of a Birge-style closing net (Wildlife Supply Co. 21-A15) through the water column. This net is made of $80-\mu \mathrm{m}$ nylon mesh and has a mouth with a diameter of $12.7 \mathrm{~cm}$ ( 5 inches). This collects net plankton, which includes the largest zooplankton or ichthyoplankton and most rotifers except for smaller nanoplankton. This type of net allows plankton to be collected from a single vertical tow to the water surface or between discrete depths in the water column because the mouth of the net can be closed at specified depths. Sample collection information was stored with other sampling observations and measurements in the Zooplankton Catalog table (tblZooplankton Catalog) of the WQDB.

Most samples were collected from a tow through the top $30 \mathrm{~m}$ of the water column, except when bottom depths dictated a shorter tow. In addition, samples from 30 to $60 \mathrm{~m}$ were collected at the Wahweap forebay station (fig. 1) to estimate plankton concentrations at the penstock withdrawal elevation of 1,058 m $(3,470 \mathrm{ft})$. Samples from the Glen Canyon Dam tail water and inflow tributaries were collected by passing known volumes of water, usually 100 to $300 \mathrm{~L}$, through the $80-\mu \mathrm{m}$ mesh of the plankton net. The contents of the sample remaining in the net were then collected into sample bottles and preserved with acid Lugols solution until analyzed. When sampling from the Glen Canyon Dam draft tubes, initial measurements of flow rate were made by measuring the time required to fill a bucket of a given volume from a sampling spigot, after which the flow was routed through the net for a known period of time.

Analysis consisted of enumeration and identification to the species level and determination of biomass for each species. Enumeration and identification were performed following the Utermohl counting chamber method using a phase-contrast inverted microscope, described by Lund and others (1958). Samples were homogenized and subsampled prior to analysis. Biomass determination was estimated by measuring the length of up to 10 individuals and applying established species-specific length/width relationships obtained from the published literature (Dumont and others, 1975; McCauley, 1984; Lawrence and others, 1987). Zooplankton analysis was performed by BSA Environmental Services, Inc., Beachwood, Ohio.

\section{Results and Data Management}

Sample collection and analysis information was cataloged in the WQDB, which also contains physical and chemical data from Lake Powell from 1964 to 2011 (Vernieu, 2015). Analyses were compiled into separate tables and linked to the sample catalog tables by common fields. The relationships between the various biological tables in the WQDB are shown in figure 2. Linkage of the biological tables with other tables in the WQDB provides the ability to compare the biological data with other physical and chemical water-quality factors.

Chlorophyll sample collection information is stored in the table tblChlorophyll Catalog and linked to the site visits table (tblSurface) by common values of the fields Date and Station ID. The results of the spectrophotometric chloprophyll analysis are stored in the table tblChlorophyll Analyses and linked on common sample identification values. 
Biological Data for Water in Lake Powell and from Glen Canyon Dam Releases, Utah and Arizona, 1990-2009

Phytoplankton and zooplankton sample collection information is stored in the tables tblPhytoplankton Catalog and tblZooplankton Catalog, respectively. Analytical results from the identification and enumeration of these samples are stored in the tables tblPhytoplankton Analyses and tblZooplankton Analyses, respectively, and linked on common sample identification values.

\section{References Cited}

Angradi, T.R., Clarkson, R.W., Kinsolving, D.A., Kubly, D.M., and Morgensen, S.A., 1992, Glen Canyon Dam and the Colorado River; responses of the aquatic biota to dam operations: Prepared for Bureau of Reclamation, Upper Colorado Region, Glen Canyon Environmental Studies, Cooperative agreement No. 9-FC-40-07940, Arizona Fish and Game Department, 155 p., accessed April 21, 2015, at http://www.riversimulator.org/ Resources/GCMRC/Aquatic/Angradi1992.pdf.

Ayers, A.D., and McKinney, T., 1996, Water chemistry and zooplankton in the Lake Powell forebay, Glen Canyon Dam discharge and tailwater: Prepared for Bureau of Reclamation, Upper Colorado Region, Glen Canyon Environmental Studies, Cooperative agreement No. 9-FC-40-07940, Arizona Game and Fish Department. 30 p., accessed April 21, 2015, at http://www. riversimulator.org/Resources/GCMRC/LakePowell/ Ayers1995.pdf.

Blinn, D.W., Tompkins, T., and Stewart, A.J., 1976, Seasonal light characteristics for a newly formed reservoir in southwestern USA: Hydrobiologia, v. 51, no. 1, p. 77-84, http://dx.doi.org/10.1007/BF00007988.

Clesceri, L.S., Greenberg, A.E., and Eaton, A.D., eds., 1999, Standard methods for the examination of water and wastewater (20th ed.): Washington, D.C., American Public Health Association, American Water Works Association, Water Environment Federation, 1,325 p.

Dumont, H.J., Van de Velde, I., and Dumont, S., 1975, The dry weight estimate of biomass in a selection of Cladocera, Copepoda and Rotifera from the plankton, periphyton and benthos of continental waters:

Oecologia, v. 19 , no. 1 , p. 75-97, http://dx.doi.org/10.1007/BF00377592.

Ferrari, R.L., 1988, 1986 Lake Powell survey: Bureau of Reclamation Report No. REC-ERC-88-6, 68 p., accessed April 21, 2015, at http://www.usbr.gov/pmts/ sediment/projects/ReservoirSurveys/Reports/1986 Lake Powell Survey.pdf.
Haury, L.R., 1986, Zooplankton of the Colorado River; Glen Canyon Dam to Diamond Creek: Glen Canyon Environmental Studies, Aquatic biology of the Glen Canyon Environmental Studies, 59 p., accessed April 21, 2015, at http://www.gcmrc.gov/library/reports/biological/Foodbase/ Haury 1986.pdf.

Horne, A.J., and Goldman, C.R., 1994, Limnology (2nd ed.): New York, McGraw-Hill, Inc., 576 p.

Hutchinson, G.E., 1967, A treatise on limnology, vol. 2; Introduction to lake biology and the limnoplankton: New York, John Wiley and Sons, Inc., 1,115 p.

Jeffery, S.W., and Humphrey, G.F., 1975, New spectrophotometric equations for determining chlorphylls $a, b$, and $c_{1}$, and $c_{2}$ in higher plants, algae and natural phytoplankton: Biochemie und Physiologie der Pflanzen, v. 167, p. 191-194.

Lawrence, S.G., Malley, D.F., Findlay, W.J, MacIver, M.A., and Delbaere, I.L., 1987, Method for estimating dry weight of freshwater planktonic crustaceans from measures of length and shape: Canadian Journal of Fisheries and Aquatic Sciences, v. 44, p. 264-274, accessed April 21, 2015, at http://www.nrcresearchpress.com/doi/pdf/10.1139/f87-301.

Lund, J.W.G., Kipling, C., and LeCren, E.D., 1958, The inverted microscope method of estimating algal numbers and the statistical basis of estimates by counting: Hydrobiologia, v. 11, no. 2, p. 143-170, http://dx.doi. org/10.1007/BF00007865.

McCauley, E., 1984, The estimation of the abundance and biomass of zooplankton in samples, in J.A. Downing, J.A., and Rigler, F.H., eds., A manual on methods for the assessment of secondary productivity in fresh waters $(2 \mathrm{~d}$ ed.): Oxford, Blackwell Scientific Publishers, p. 228-265, accessed April 21, 2015, at http://www.public.iastate. edu/ downing/tier 2/jadpdfs/1984 IBP 17 Chapter 7 Abundance and Biomass of Zooplankton.pdf.

Mueller, G., and Horn, M.J., 1999, Description of the pelagic zooplankton and fish communities of Lakes Powell and Mead: U.S. Geological Survey Open-File Report 1999-109, 449 p., accessed April 21, 2015, at http://pubs.usgs.gov/ of/1999/0109/report.pdf.

Sollberger, P., Vaux, P.D., and Paulson, L.J., 1988, Investigation of vertical and seasonal distribution, abundance and size structure of zooplankton in Lake Powell: Lake Mead Limnological Research Center, University of Nevada, Las Vegas, 263 p., accessed April 21, 2015, at http://www.gcmrc.gov/library/reports/biological/Lake_ Powell/Sollberger1988.pdf. 
Stanford, J.A., and Ward, J.V., 1991, Limnology of Lake Powell and the chemistry of the Colorado River, in Committee to Review the Glen Canyon Environmental Studies Water Science and Technology Board, ed., Colorado River ecology and dam management: Washington, D.C., May 24-25, 1990, Proceedings: National Academy Press, p. 75-101.

Stewart, A.J., Blinn, D.W., Tompkins, T., and Wilkes, S., 1974, Phytoplankton population dynamics in Warm Creek Bay, Lake Powell, in Environmental impact studies of the Navajo and Kaiparowits power plants, Third annual report: Northern Arizona University, 149 p.

Stewart, A.J., and Blinn, D.W., 1976, Studies on Lake Powell, USA; Environmental factors influencing phytoplankton success in a high desert warm monomictic lake: Archiv für Hydrobiologie, v. 78, no. 2, p. 139-164.

Stone, J.L., 1966, Reservoir fisheries investigation; creel census and plankton studies: Arizona Game and Fish Department, $40 \mathrm{p}$.

Stone, J.L., 1967, Reservoir fisheries investigation; creel census and plankton studies: Arizona Game and Fish Department, 41 p., accessed April 21, 2015, at http://www.nativefishlab. net/library/textpdf/14589.pdf.

Stone, J.L., and Queenan, A.B., 1967, Tailwater fisheries investigation; creel census and limnological study of the Colorado River below Glen Canyon Dam: Arizona Game and Fish Department, 33 p.
Stone, J.L., and Rathbun, N.L., 1968a, Lake Powell fisheries investigation; creel census and plankton studies: Arizona Game and Fish Department, 56 p.

Stone, J.L., and Rathbun, N.L., 1968b, Tailwater fisheries investigation; creel census and limnological study of the Colorado River below Glen Canyon Dam: Arizona Game and Fish Department, $39 \mathrm{p}$.

Stone, J.L., and Rathbun, N.L., 1969a, Lake Powell fisheries investigation; creel census and plankton studies: Arizona Game and Fish Department, 61 p.

Stone, J.L., and Rathbun, N.L., 1969b, Tailwater fisheries investigation; creel census and limnological study of the Colorado River below Glen Canyon Dam: Arizona Game and Fish Department, 35 p.

Thornton, K.W., Kimmel, B.L., and Payne, F.E., eds., 1990, Reservoir limnology; Ecological perspectives: New York, John Wiley and Sons, Inc., 246 p.

Vernieu, W.S., 2015, Historical physical and chemical data for water in Lake Powell and from Glen Canyon Dam releases, Utah-Arizona, 1964-2013 (ver. 3.0, February 2015): U.S. Geological Survey Data Series 471, 23 p., http://dx.doi.org/10.3133/ds471.

Wetzel, R.G., 2001, Limnology; lake and river ecosystems (3d ed.): San Diego, Calif., Academic Press, 1006 p. 


\section{Appendix 1. Database Table Descriptions}

This appendix contains a description of the various biological data tables in the WQDB (a nominal acronym for water-quality database). Each section contains a brief description of each table, the fields and attributes of each table, notes about linkages to other tables, and summary statistics of each table. For descriptions of other tables in the WQDB, see Vernieu (2015). Descriptions of the Stations table and the Surface table have been repeated here because they form the primary linkages with the biological tables. Under the FieldSize property for the data field in each table, "Single" refers to single-point precision, with a storage size of 4 bytes; "Double" refers to double-point precision, with a storage size of 8 bytes. Figure 2 shows the graphical relationships between the tables of the WQDB.

\section{Stations Table}

The Stations table (tblStations) describes the various sampling sites at which monitoring activities occur on Lake Powell (fig. 1). A single sampling site is identified by the eight-character STATION ID field, which uniquely identifies each record in the table. The fields in the Stations table are listed in table 1-1.

The STATION ID field describes the location of a sampling site by including the stream channel in which it is located and the river-channel distance, in tenths of kilometers, from Glen Canyon Dam or a tributary confluence. Under the current naming convention, the first two letters reference the project (LP for Lake Powell), the next two or three characters designate the tributary arm or stream channel (CR for Colorado River, SJR for San Juan River, ESC for Escalante River), and the remaining three or four digits designate the river-channel distance, in tenths of kilometers, of the station from a given reference point. That reference point is usually the confluence of a tributary arm with the main channel. For the Colorado River channel, the reference point is Glen Canyon Dam. For example, the Cha Canyon station, which is located 19.3 river-channel kilometers from the pre-dam Colorado River channel on the San Juan River arm of Lake Powell, has a value for the STATION ID field of LPSJR193. For stations below Glen Canyon Dam, the river-channel distance is negative. For example, LPCR-249 represents the Colorado River at Lees Ferry station, 24.9 river-channel kilometers below Glen Canyon Dam. The specific location for a given station is listed in the Stations table as latitude and longitude coordinates in decimal degrees.

Information regarding sampling locations is stored in the WQDB according to the specific STATION ID in effect at the time of sampling and the more general STATION GROUP. Sampling locations representative of a given general location on the reservoir (STATION GROUP) may have many different STATION IDs recorded in the database. This is because different naming conventions have been used during the monitoring history of Lake Powell and because the specific sampling location for a given site may have been slightly adjusted over time to facilitate sampling conditions (because of boat traffic, wind patterns, or local sedimentation). Multiple STATION ID values may also exist for tributary inflow sites on the reservoir and Glen Canyon Dam release sites. Depending on reservoir elevation at the time of sampling, the actual location of an inflow sampling site may vary over a relatively large distance. Releases from Glen Canyon Dam may be sampled from any of eight generating turbine draft tubes or from the tailrace immediately below Glen Canyon Dam. The STATION GROUP field is therefore used to collectively reference multiple STATION IDs to a single representative location on the reservoir. All records in the Stations table that are representative of a single location on the reservoir will have a common value for the STATION GROUP field. For example, the STATION GROUP values of LPCR_INF, LPSJRINF, and LPESCINF collectively group various inflow sites on the Colorado, San Juan, and Escalante River arms of the reservoir, respectively. The STATION GROUP value of LPCR0000 collectively groups all sampling locations representative of Glen Canyon Dam releases. By selecting all records in the Stations table for common values of a given STATION GROUP code, the entire history for that site can be retrieved, regardless of the specific STATION ID value in effect at the time of sampling.

Twenty-seven primary stations were established at which quarterly monitoring was performed (table 1). Some primary stations were not always sampled because of low reservoir elevations, and other nonprimary stations were occasionally sampled where interesting or unusual conditions existed. Currently, 21 to 37 stations may be sampled on a given quarterly survey.

There are 167 sampling sites described in the Stations table. Of this number, 150 correspond to the 27 primary station groups shown in table 1 . The remaining 17 sites represent occasional sampling and are not part of the current monitoring program. The 27 primary station groups represent the current biological monitoring program and long-term sampling sites. These groups are designated by the PRIMARY GROUP field. The geographical coordinates, stream channel designation, and river channel distances for the 27 primary groups are listed in table 1 .

\section{Surface Table}

The Surface table (tblSurface) contains a record of every site visit at which water-quality measurements have been made on Lake Powell. It contains observations made on arrival (DATE) at a given sampling site (STATION ID) and includes information about who collected the measurements and how they were collected, reservoir elevation and depth, general meteorological conditions, and other comments. Each record is uniquely identified by the time of the site visit (DATE) and the location of the site visit (STATION ID). See table 1 for the number of Surface table entries or site visits for each primary station group.

The TRIP ID field is a useful way to group all site visits within a given monitoring survey. The value of the TRIP ID field is in the format LPyymmdd, where yymmdd corresponds 
to the date of the first reservoir sample collected during the monitoring survey. The fields comprising the Surface table are listed in table 1-2.

There are currently 1,900 records of site visits for which biological samples were collected in the Surface table. Of this number, 1,816 (95.6 percent) represent site visits related to the 27 primary station groups shown in table 1 . The remaining 84 (4.4 percent) site visits represent occasional sampling at sites not part of the current monitoring program.

\section{Chlorophyll Catalog Table}

The Chlorophyll Catalog table (tblChlorophyll Catalog) provides a catalog of all samples collected for chlorophyll analysis during a given site visit and serves as a link between the Surface table (tblSurface) and the Chlorophyll Analyses table (tblChlorophyll Analyses), which contains the results of spectrophotometric chlorophyll analyses. Each record can be linked with a site visit record in the Surface table by the fields STATION ID and DATE. The SAMPLE ID field is a field-assigned number, most often formatted as yymm-99, with yymm representing the year and month of collection and 99 representing a sequential collection number. Linkage with the corresponding Chlorophyll Analyses table is made through common values of SAMPLE ID. Each record in the Chlorophyll Catalog table is uniquely identified by time of the site visit (DATE), the location of the site visit (STATION ID), and the sample identification number (SAMPLE ID). The fields included in the Chlorophyll Catalog table are listed in table 1-3.

Table 1-1. Data fields and attributes of tblStations.

[* indicates primary field that uniquely identifies each record in the table; $\mathrm{km}$, kilometers]

\begin{tabular}{llcl}
\hline \multicolumn{1}{c}{ Field name } & Type & Field size & \multicolumn{1}{c}{ Description } \\
\hline *STATION ID & Text & 10 & Site identifier code. \\
SITE NAME & Text & 50 & Descriptive site name. \\
LATITUDE & Number & Double & Latitude (decimal degrees). \\
LONGITUDE & Number & Double & Longitude (decimal degrees). \\
CHANNEL & Text & 5 & Stream channel of site location. \\
RKM & Number & Single & River channel distance (km). \\
STATION GROUP & Text & 10 & Station grouping identifier. \\
PRIMARY GROUP? & Yes/No & 1 & Primary group designation. \\
\hline
\end{tabular}

Table 1-2. Data fields and attributes of tblSurface.

[* indicates primary fields that uniquely identify each record in the table; $\mathrm{ft}$, feet; $\mathrm{m}$, meters; $\mathrm{cm}$, centimeters; mph, miles per hour; F, Fahrenheit; C, Celsius]

\begin{tabular}{llcl}
\multicolumn{1}{c}{ Field name } & \multicolumn{1}{c}{ Type } & Field size & \multicolumn{1}{c}{ Description } \\
\hline *DATE & Date/Time & 15 & Date and time of site visit. \\
*STATION ID & Text & 10 & Site identifier code. \\
TRIP ID & Text & 10 & Monitoring survey identifier. \\
PROFILERS & Text & 24 & Names or initials of observers. \\
INSTRUMENT & Text & 20 & Designation of profiling instrument. \\
VESSEL & Text & 20 & Designation of sampling vessel. \\
ELEVATION & Number & Single & Reservoir elevation (ft). \\
BOTTOM SOUNDING & Number & Single & Bottom sounding (m). \\
WAVE HEIGHT & Text & 20 & Wave height description (cm). \\
WIND & Text & 20 & Wind speed description (mph). \\
AIR TEMP & Number & Single & Numeric air temperature. \\
AIR TEMP UNITS & Text & 1 & Air temperature units (F or C). \\
CLOUD COVER & Text & 10 & Cloud cover-verbal (percent). \\
\hline
\end{tabular}

Table 1-3. Data fields and attributes of tblChlorophyll Catalog.

[* indicates primary fields that uniquely identify each record in the table; m, meters; ml, milliliters]

\begin{tabular}{llcl}
\hline \multicolumn{1}{c}{ Field name } & \multicolumn{1}{c}{ Type } & Field size & \multicolumn{1}{c}{ Description } \\
\hline *DATE & Date/Time & 15 & Date and time of site visit. \\
*STATION ID & Text & 10 & Site identifier code. \\
*SAMPLE ID & Text & 10 & Unique sample identifier. \\
OBSERVER & Text & 5 & Initials of observer. \\
DEPTH & Number & Single & Depth of sample (m). \\
VOLUME & Number & Double & Volume filtered (ml). \\
COMMENTS & Text & 100 & Sample collection comments. \\
\hline
\end{tabular}


There are currently 2,051 observations in the Chlorophyll Catalog table, representing samples collected from January 27, 1992, to December 22, 2009. These are linked with 2,051 records in the Chlorophyll Analyses table. Of this number, 1,959 (95.5 percent) represent samples at the 27 primary station groups shown in table 1 . The remaining 92 (4.5 percent) samples represent occasional sampling at sites not part of the current monitoring program.

\section{Chlorophyll Analyses Table}

The Chlorophyll Analyses table contains the results of spectrophotometric analyses of chlorophyll samples. Each record is uniquely identified by the field SAMPLE ID, which forms a link between the Chlorophyll Catalog and Chlorophyll Analyses tables. The fields in the table contain concentrations of chlorophyll $a, b$, and $c$ and pheophytin $a$ and are described in table 1-4. There are currently 2,051 observations for chlorophyll analyses.

\section{Phytoplankton Catalog Table}

The Phytoplankton Catalog table (tblPhytoplankton Catalog) provides a catalog of all samples collected for phytoplankton analysis during a given site visit and serves as a link between the Surface table (tblSurface) and the Phytoplankton Analyses table (tblPhytoplankton Analyses), which contains the results of identification, enumeration, and biovolume estimation of phytoplankton samples. Each record can be linked with a site visit record in the Surface table by the fields STATION ID and DATE. The LAB ID PHY field is a fieldassigned number, most often formatted as yymm-99, with yymm representing the year and month of collection and 99 representing a sequential collection number. Linkage with the corresponding Phytoplankton Analyses table is made through common values of LAB ID PHY and LAB ID in the Phytoplankton Analyses table. Each record in the Phytoplankton Catalog table is uniquely identified by time of the site visit (DATE), the location of the site visit (STATION ID), and the sample identification number (FIELD ID). The fields included in the Phytoplankton Catalog table are listed in table 1-5.

There are currently 1,397 observations in the Phytoplankton Catalog table, representing samples collected from April 24, 1992, to December 22, 2009. These are linked with 20,711 records in the Phytoplankton Analyses table. Of this number, 1,366 (97.8 percent) represent samples at the 27 primary station groups shown in table 1 . The remaining 31 (2.2 percent) samples represent occasional sampling at sites not part of the current monitoring program.

\section{Phytoplankton Analyses Table}

The Phytoplankton Analyses table contains the results of the identification, enumeration, and biovolume estimation of phytoplankton samples. Each record is uniquely identified by the field LAB ID, which forms a link between the Phytoplankton Catalog and Phytoplankton Analyses tables. The fields in the table contain values for the combined genus and species of an identified organism (GENUS SPECIES), the abundance of this organism in cells per liter (cells/L), and the estimated biovolume of the organisms in the sample in cubic micrometers per liter $\left(\mu \mathrm{m}^{3} / \mathrm{L}\right)$ and are listed in table $1-6$. There are currently 20,711 records in the Phytoplankton Analyses table representing the analysis of 1,397 phytoplankton samples.

\section{Phytoplankton Taxonomy Table}

The Phytoplankton Taxonomy table, (tblPhytoplankton Taxonomy) contains a listing of the combined genus and species of each identified organism and the major taxonomic division to which the organism belongs (for example, Chrysophyta, Cyanobacteria). The purpose of this table is to aid summarization of abundance and biovolume of organisms in major taxonomic groups. The fields contained in the Phytoplankton Taxonomy table are listed in table 1-7.

The Phytoplankton Taxonomy contains 646 records, representing the genus and species of each identified organism and its taxonomic division.

\section{Zooplankton Catalog Table}

The Zooplankton Catalog table (tblZooplankton Catalog) provides a catalog of all samples collected for zooplankton analysis during a given site visit and serves as a link between the Surface table (tblSurface) and the Zooplankton Analyses table (tblZooplankton Analyses), which contains the results of identification, enumeration, and biovolume estimation of zooplankton samples. Each record can be linked with a site visit record in the Surface table by the fields STATION ID and DATE. The LAB ID PHY field is a field-assigned number, most often formatted as yymm-99, with yymm representing the year and month of collection and 99 representing a sequential collection number. Linkage with the corresponding Zooplankton Analyses table is made through common values of LAB ID PHY and LAB ID in the Zooplankton Analyses table. Each record in the Zooplankton Catalog table is uniquely identified by time of the site visit (DATE), the location of the site visit (STATION ID), and the sample identification number (FIELD ID). The fields included in the Zooplankton Catalog table are listed in table $1-8$.

There are currently 1,898 observations in the Zooplankton Catalog table, representing samples collected from December 4, 1990, to December 22, 2009. These are linked with 18,048 observations in the Zooplankton Analyses table. Of this number, 1,861 (98.1 percent) represent samples at the 27 primary station groups shown in table 1 . The remaining 37 (1.9 percent) samples represent occasional sampling at sites not part of the current monitoring program. 
Table 1-4. Data fields and attributes of tbIChlorophyll Analyses.

[* indicates primary field that uniquely identifies each record in the table; $\mathrm{mg} / \mathrm{m}^{3}$, milligrams per cubic meter]

\begin{tabular}{llcl}
\hline \multicolumn{1}{c}{ Field name } & Type & Field size & \multicolumn{1}{c}{ Description } \\
\hline *SAMPLE ID & Text & 10 & Unique sample identifier. \\
CHL_A & Number & Double & Concentration of chlorophyll $a\left(\mathrm{mg} / \mathrm{m}^{3}\right)$. \\
CHL_A_D & Text & 5 & Descriptor field indicating value below specified detection limit. \\
CHL_B & Number & Double & Concentration of chlorophyll $b\left(\mathrm{mg} / \mathrm{m}^{3}\right)$. \\
CHL_B_D & Text & 5 & Descriptor field indicating value below specified detection limit. \\
CHL_C & Number & Double & Concentration of chlorophyll $c\left(\mathrm{mg} / \mathrm{m}^{3}\right)$. \\
CHL_C_D & Text & 5 & Descriptor field indicating value below specified detection limit. \\
PHEO_A & Number & Double & Concentration of pheophytin $a\left(\mathrm{mg} / \mathrm{m}^{3}\right)$. \\
PHEO_A_D & Text & 5 & Descriptor field indicating value below specified detection limit. \\
\hline
\end{tabular}

Table 1-5. Data fields and attributes of tblPhytoplankton Catalog.

[* indicates primary field that uniquely identifies each record in the table; $\mathrm{m}$, meters]

\begin{tabular}{llcl}
\multicolumn{1}{c}{ Field name } & Type & Field size & \multicolumn{1}{c}{ Description } \\
\hline DATE & Date/Time & 15 & Date and time of site visit. \\
STATION ID & Text & 10 & Site identifier code. \\
*LAB ID PHY & Text & 10 & Sample identifier, laboratory. \\
DEPTH & Text & 10 & Depth of discrete phytoplankton sample (m). \\
COMPOSITE DEPTH & Text & 10 & Bottom depth, if composite sample (m). \\
\hline
\end{tabular}

Table 1-6. Data fields and attributes of tblPhytoplankton Analyses.

[* indicates primary fields that uniquely identify each record in the table; $\# / \mathrm{L}$, number per liter; $\mu \mathrm{m}^{3} / \mathrm{L}$, cubic micrometers per liter ]

\begin{tabular}{llcl}
\hline \multicolumn{1}{c}{ Field name } & Type & Field size & \multicolumn{1}{c}{ Description } \\
\hline${ }^{*}$ LAB ID & Text & 10 & Unique sample identifier. \\
*GENUS_SPECIES & Number & 60 & Combined genus and species of identified organism. \\
ABUNDANCE & Number & Double & Density of organism, $(\# / L)$. \\
BIOVOLUME & Number & Double & Biovolume of identified organism, $\left(\mu \mathrm{m}^{3} / \mathrm{L}\right)$. \\
\hline
\end{tabular}

Table 1-7. Data fields and attributes of tbIPhtyoplankton Taxonomy.

[* indicates primary field that uniquely identifies each record in the table]

\begin{tabular}{llcl}
\hline \multicolumn{1}{c}{ Field name } & Type & Field size & \multicolumn{1}{c}{ Description } \\
\hline *GENUS_SPECIES & Text & 60 & Combined genus and species of identified organism. \\
DIVISION & Text & 30 & Major taxonomic division. \\
GENUS & Text & 50 & Genus of specified organism. \\
SPECIES & Text & 50 & Species of specified organism. \\
\hline
\end{tabular}

Table 1-8. Data fields and attributes of tblZooplankton Catalog.

[* indicates primary field that uniquely identifies each record in the table; $\mathrm{m}$, meters]

\begin{tabular}{llcl}
\hline \multicolumn{1}{c}{ Field name } & Type & Field size & \multicolumn{1}{c}{ Description } \\
\hline DATE & Date/Time & 15 & Date and time of site visit. \\
STATION ID & Text & 10 & Site identifier code. \\
*LAB ID ZOO & Text & 10 & Sample identifier, laboratory. \\
TOP DEPTH & Text & 10 & Top depth of composite sample $(\mathrm{m})$. \\
BOTTOM DEPTH & Text & 10 & Bottom depth of composite sample $(\mathrm{m})$. \\
\hline
\end{tabular}




\section{Zooplankton Analyses Table}

The Zooplankton Analyses table contains the results of the identification, enumeration, and biomass estimation of zooplankton samples. Each record is uniquely identified by the field LAB ID, which forms a link between the Zooplankton Catalog and Zooplankton Analyses table. The fields in the table contain values for the combined genus and species of an identified organism (GENUS SPECIES), the abundance of this organism in cells per liter (cells/L), and the estimated biomass of the organisms in the sample in micrograms dry weight per liter $\left(\mu \mathrm{g}^{3} / \mathrm{L}\right)$ and are listed in table 1-9. There are currently 18,048 observations in the Zooplankton Analyses table, representing the analysis of 1,898 zooplankton samples.

\section{Zooplankton Taxonomy Table}

The Zooplankton Taxonomy table (tblZooplankton Taxonomy) contains a listing of the combined genus and species of each identified organism and the major taxonomic division to which the organism belongs (for example, Cladocerans, Copepods). The purpose of this table is to aid summarization of abundance and biovolume of organisms in major taxonomic groups. The fields contained in the Zooplankton Taxonomy table are listed in table 1-10. The Zooplankton Taxonomy table contains 114 records, representing the genus and species of each identified organism and its taxonomic division.

Table 1-9. Data fields and attributes of tblZooplankton Analyses.

[* indicates primary fields that uniquely identify each record in the table; \#/L, number per liter; $\mu \mathrm{m}^{3} / \mathrm{L}$, cubic micrometers per liter]

\begin{tabular}{llcl}
\hline \multicolumn{1}{c}{ Field name } & Type & Field size & \multicolumn{1}{c}{ Description } \\
\hline *LAB ID & Text & 10 & Unique sample identifier. \\
*GENUS_SPECIES & Number & 60 & Combined genus and species of identified organism. \\
ABUNDANCE & Number & Double & Density of organism, $(\# / \mathrm{L})$. \\
BIOMASS & Number & Double & Biomass of identified organism, $\left(\mu \mathrm{g}^{3} / \mathrm{L}\right)$. \\
\hline
\end{tabular}

Table 1-10. Data fields and attributes of tblZooplankton Taxonomy.

[* indicates primary field that uniquely identifies each record in the table]

\begin{tabular}{lccl}
\hline \multicolumn{1}{c}{ Field name } & Type & Field size & \multicolumn{1}{c}{ Description } \\
\hline *GENUS_SPECIES & Text & 60 & Combined genus and species of identified organism. \\
DIVISION & Text & 30 & Major taxonomic division. \\
GENUS & Text & 40 & Genus of identified organism. \\
SPECIES & Text & 40 & Species of identified organism. \\
\hline
\end{tabular}


Produced in the Menlo Park Publishing Service Center, California Manuscript approved on August 24, 2015 Edited by Jessica L. Dyke Layout by Cory D. Hurd 
